\title{
Martenscypridopsis a new ostracod genus (Crustacea : Ostracoda) from African inland waters
}

\author{
I. Karanovic ${ }^{1}$ \\ G.L. Pesce ${ }^{2}$
}

Keywords : Ostracoda, Cypridopsinae, Martenscypridopsis, Africa.

Martenscypridopsis n. gen. and Martenscypridopsis materia n. sp. from Algerian inland waters are described. The new genus belongs to the group of genera in the subfamily Cypridopsinae where the right valve overlaps the left one both anteriorly and ventrally; it is also the second genus within the subfamily where both sexes completely lack the furca. The new genus includes also the species Martenscypridopsis pygmea (Sars, 1924) n. comb., from South and Central Africa.

\section{Martenscypridopsis, nouveau genre d'ostracodes des eaux douces de l'Afrique}

Mots clés : Ostracoda, Cypridopsinae, Martenscypridopsis, Afrique.

Les auteurs décrivent le nouveau genre Maríenscypridopsis pour la nouvelle espèce Martenscypridopsis materia trouvée dans les eaux douces souterraines de l'Algérie. Le nouveau genre appartient au groupe des genres de la sous-famille des Cypridopsinae qui ont la valve droite qui surmonte antérieurement et ventralement la valve gauche. Il s'agit du deuxième genre dans cette sous-famille avec absence de furca dans les deux sexes. Le nouveau genre comprend aussi l'espèce Martenscypridopsis pygmea (Sars, 1924) n. comb. connue d'Afrique centrale et méridionale.

\section{Introduction}

The number of species included in the subfamily Cypridopsinae Kaufmann, 1900 is very difficult to establish. The most important reasons for this situation are old, and often insufficient descriptions of many species (Sars 1903, 1924). According to the check list of non-marine ostracods from African inland waters, provided by Martens (1984), about 110 Cypridopsinae species have been described from that continent. Among those species many are still in doubt. In the taxonomy of Cypridopsinae the main distinguishing generic features are :

1. the shape of valves as well as their way of overlapping ;

2. the shape of terminal segment of maxillular palp ;

3. the shape of furca.

1. Via Brescia 3, 84092 Bellizzi (SA), Italy.

2. Dipartamento di Scienze Ambientali, Universita di L'Aquila, via Vetoio 14, 67100 Coppito, L'Aquila, Italy.
But, rearly one can find in old papers all those features described (Sars 1903, 1924 ; Klie 1939, 1944 etc.). So, for many species correct position, within one of 14 Cypridopsinae genera known so far, remains uncertain. The greatest number of this variety of species are still refered to the genus Cypridopsis Brady, 1867. Recently, on the basis of an old type material, as well as new collected one, some new genera were described (see Martens 1985, 1991 ; Karanovic 1999), what only partly resolved existing problems within subfamily. During the examination of material collected in 1973 from North Africa by research group from the University "La Sapienza" in Rome (Italy) we have found one very interesting Cypridopsinae species and herein described it as Martenscypridopsis materia n. gen., n. sp., a type species of the new genus also described in the present paper. The genus Martenscypridopsis $\mathrm{n}$. gen. is the second in the subfamily where both males and females lack the furca. The other one is Pseudocypridopsis Karanovic, 1999 described from Montenegro (Karanovic 1999). The new genus also includes species Martenscypridopsis pygmea (Sars, 1924) n. comb., described from South Africa (Sars 1924) and later on found also in Zaire (Klie 1944). 


\section{Methods}

The samples were collected with modified Cvetkov net (Vigna Taglianti et al. 1969). The specimens were sorted under a Letz stereo-microscope in $70 \%$ ethyl alcohol. Ostracods were dissected with fine entomological needles in a mixture of distilled water and glycerol $(1: 1)$. All drawings were prepared using a camera lucida on the Leica DMLS microscope with C-plan achromat objectives. Chaetotaxy of the antenna and hemipenis are marked according to Martens (1985). The names for all other limbs are used according to Martens (1998).

Abbreviation used in the text and in the figures : $\mathrm{H}$ heigh $\mathrm{t}$; L-length ; LV-left valve ; RV-fight valve ; $\mathrm{W}$ width.

\section{Results}

Family : Cyprididae Baird, 1845

Subfamily : Cypridopsinae Kaufmann, 1900

Genus : Martenscypridopsis n. gen.

Diagnosis : Small Cypridopsinae with slightly ovoid valve form. RV overlapping LV frontally and ventrally ; LV overlapping RV caudally. Carapace smooth. Selvage peripheral. Five adductor muscle scars present. Antenna with long swimming setae. Terminal segment of maxillular palp cylindrical, 2 times longer than wide ; third endite of this appendage with two smooth claws. Hemipenis with obtuse proximal and elongated distal shield ; distal shield medially with clear hollow. Furca absent in both sexes. Genital lobe with copulatory hooks.

Derivation of the name: The genus is named after Dr. Koen Martens from the Royal Belgium Institute of Natural Sciences, in honor to his outstanding contribution to the taxonomy of Cypridopsinae ; prefixed to the genus name Cypridopsis. Gender feminine.

Type species: Martenscypridopsis materia n. sp.

Other species : Martenscypridopsis pygmea (Sars, 1924) n. comb.

\section{Martenscypridopsis materia n. sp.}

(Figs. 1-22)

Material examined: Holotype (male), allotype (female) and 12 paratypes ( 6 females, 1 male and 5 juveniles), from a freshwäter well near the village of Tindouf, Algeria. December 5th, 1973, coll. L. Boitani. Holotype, allotype, 2 paratype females and 1 paratype male are dissected and mounted on the slides in Faure's medium, while other specimens are preserved in $70 \%$ ethyl alcohol. The material is in the working collection of the first author.

Derivation of the name: The species is named after the Latin noun materia, which means substance, agreeing in gender with the feminine generic name.

Description of male (Holotype) : $\mathrm{L}=0.373 \mathrm{~mm}$. Maximum $\mathrm{H}=60 \%$ of $\mathrm{L}$, lies around middle L. Maximum $\mathrm{W}=52 \%$ of $\mathrm{L}$, lies around middle $\mathrm{L}$. In dorsal view (fig. 2) RV overlaps LV frontally ; caudally LV slightly overlaps RV. In ventral view (fig. 3 ) RV overlaps LV. Both, frontal and caudal ends rounded. In lateral view (fig. 1) dorsal margin almost regularly arched ; frontal and caudal margins almost of subequal $\mathrm{W}$, or caudal slightly narrower than frontal one. On LV caudal margin more markedly inclined towards ventral margin than on RV. Ventral margin straight or slightly convex. Selvage peripheral and developed on frontal and caudal margins on LV, and only on frontal margin on RV. LV frontally and caudally on outer margin with obtuse tubercles which, on caudal margin, passes into serrated outer margin. Line of concrescence very narrow and hardly visible on caudal end. RV with small tubercles only ventro-caudally. Marginal zone wide on anterior, narrow on posterior end. LV anteriorly, with very minute teeth situated close to line concrescence. Inner list developed and visible only on RV, posteriorly and ventraly. On LV not visible. Five adductor muscle scars present. Valve surface covered with hairs, colour jellow-brown. Antennula 7-segmented. First segment with 3 , second with 1 , third with 2 , fourth and fifth with 3 setae each. Penultimate segment with 4 setae, while terminal segment caries 3 setae and an aesthetasc (ya), 6 times longer than terminal segment. $\mathrm{L}$ ratios of 5 distal segments (from proximal to distal end) $1.7: 1.5: 1.2: 1: 1.2$. Antenna (Fig. 10) with long swimming setae, exceeding terminal claws. Aesthetase (Y) with well developed distal part. Claws very long ; G1 1.7, G2 1.8, GM 1.46 and Gm 0.79 times as long as first endopodal segment (measuring interior margin). Claw G3 reduced into strong seta; seta z1 claw-like and 4.1 times longer than terminal segment. Seta $\mathrm{z} 2$ very long; seta $\mathrm{z} 3$ missing. Aesthetascs y 2 and y 3 of subequal $L$ and 1.7 times longer than terminal segment. All claws, except $\mathrm{Gm}$ serrated. Md shown on Fig. 12 ; alpha-seta narrow and with small setulae ; beta-seta stout and hirsute ; gamma-seta long and narrow and set with setilae. Rake-like organ (Fig. 11) with 11 teeth. Maxillula (Fig. 15) with 2-segmented palp. Penultimate segment with 4 smooth setae. Terminal segment 2 times longer than wide, bearing one claw-like seta, fused with segment and 3 shorter smooth setae. Third endite caries 2 smooth claws (Fig. 14). Prehensi- 

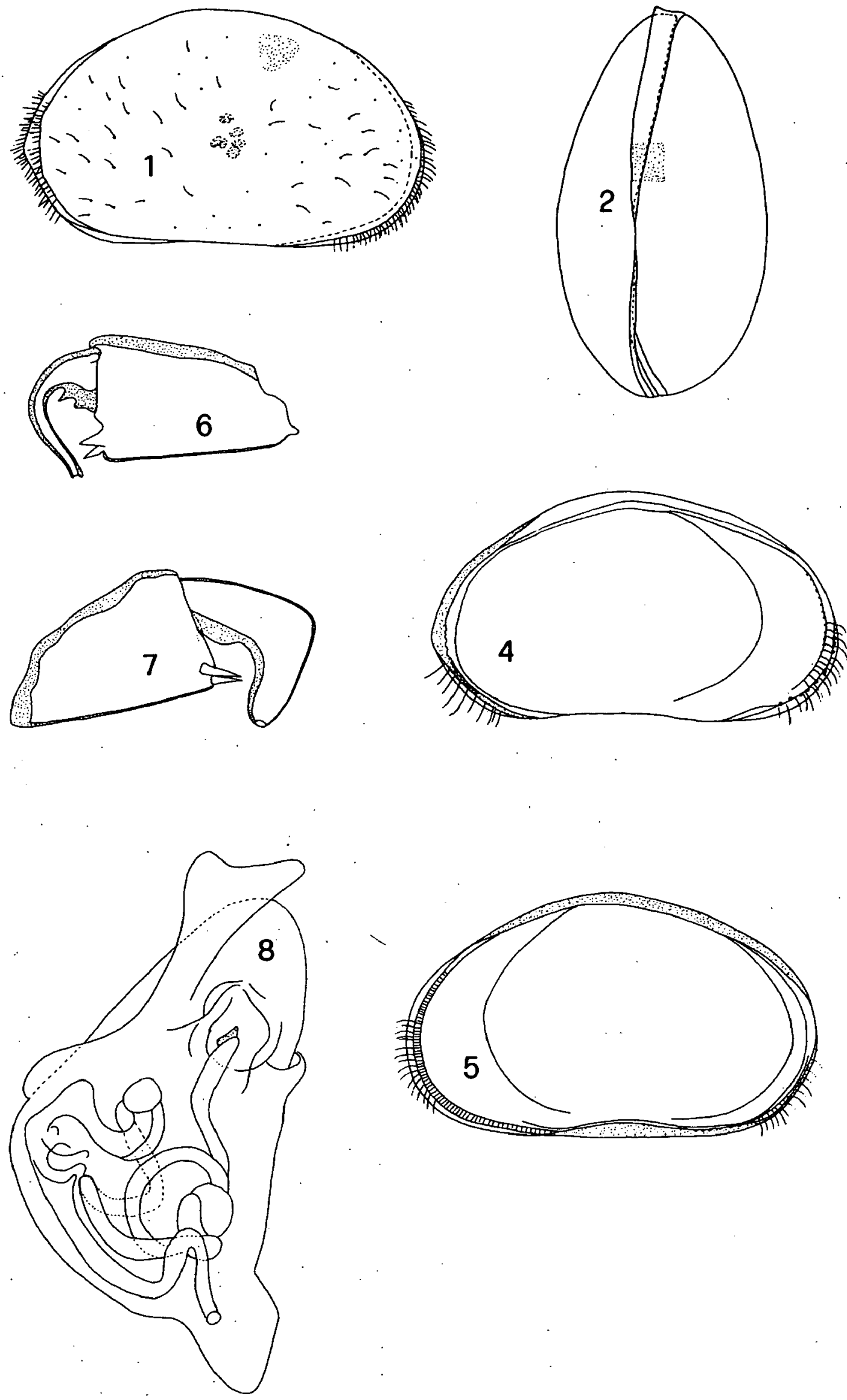

$1-5$
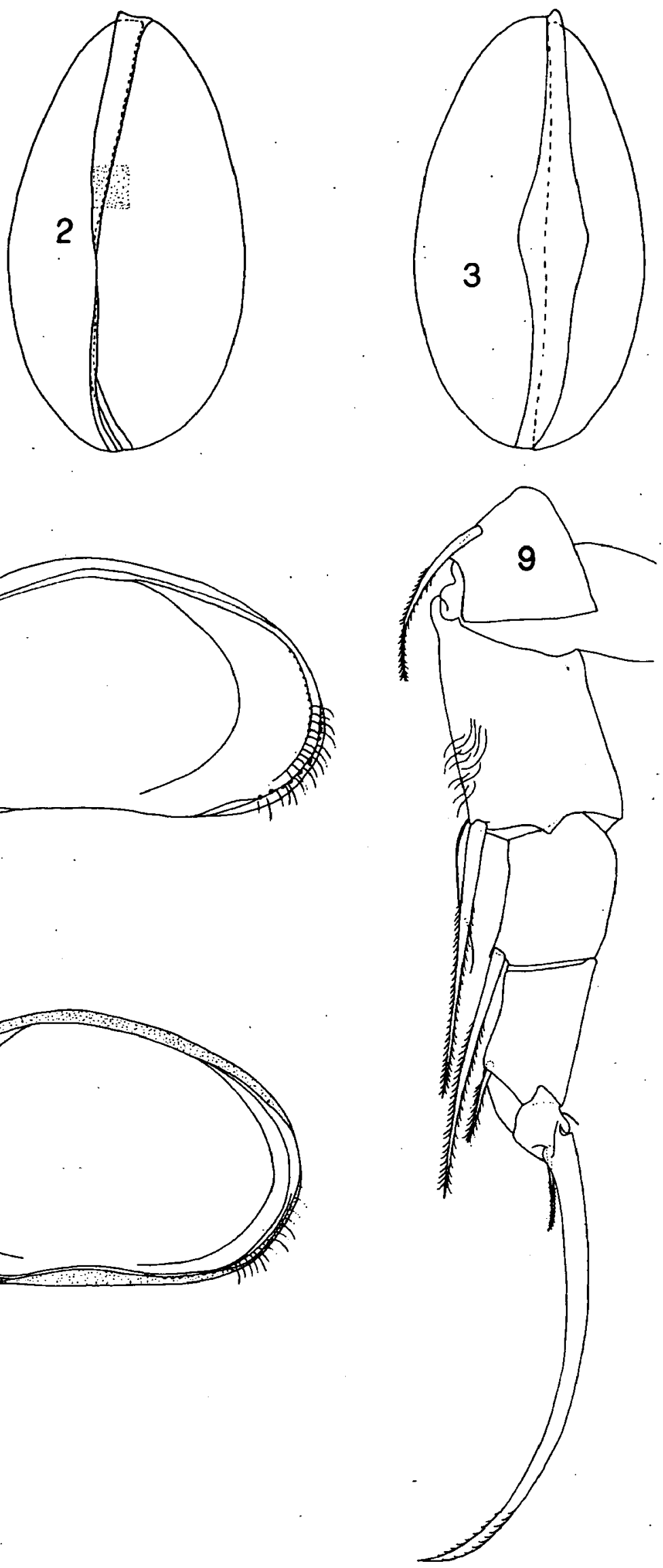

$6-9$

Figs. 1-9. Martenscypridopsis materia n. gen., n. sp. 1-3, 6-9 holotype (male $0.373 \mathrm{~mm}$ ) ; 4-5 paratype (male $0.385 \mathrm{~mm}$ ). 1-carapace, seen from the right side ; 2-carapace, dorsal view ; 3-carapace, ventral view ; 4-LV, internal view ; 5-RV, internal view ; 6-right prehensile palp ; 7-left prehensile palp ; 8-hemipenis ; 9-walking leg. Scale $=0.1 \mathrm{~mm}$.

Figs. 1-9. Martenscypridopsis materia n. gen., n: sp. 1-3, 6-9 holotype (mâle 0,373 mm); 4-5 paratype (mâle 0,385 mm). 1 -carapace, vue droite ; 2-carapace, vue dorsale ; 3-carapace, vue ventrale ; 4-valve gauche, vue interne ; 5-valve droite, vue interne ; 6-palpe préhensile droit ; 7-palpe préhensile gauche ; 8-organe copulateur mâle ; 9-2 eme thoracopode. Echelle $=0,1 \mathrm{~mm}$. 


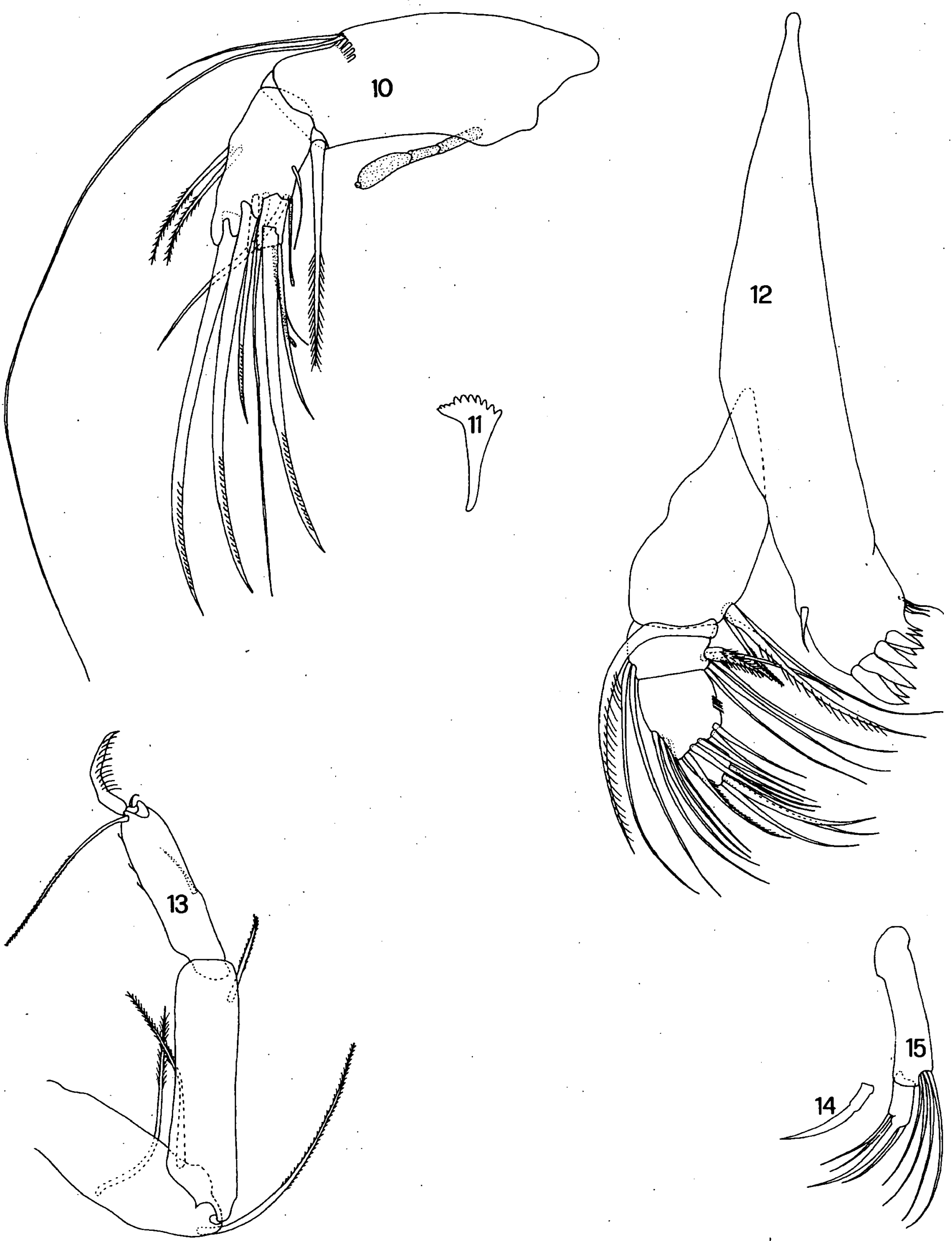

Figs. 10-15. Martenscypridopsis materia n. gen., n. sp. holotype (male $0.373 \mathrm{~mm}$ ). 10-antenna; 11-rake-like organ; 12-mandibula ; 13-cleaning leg ; 14-claw on the third endite of maxillula ; 15-maxillular palp. Scale $=0.1 \mathrm{~mm}$.

Figs. 10-15. Martenscypridopsis materia n. gen., n. sp. holotype (mâle 0,373 mm). 10-antenne ; 11-pièce en forme de râteau ; 12-mandibule ;

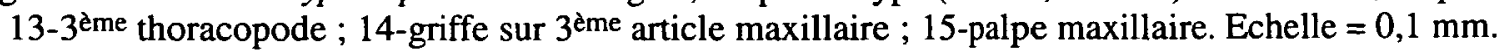



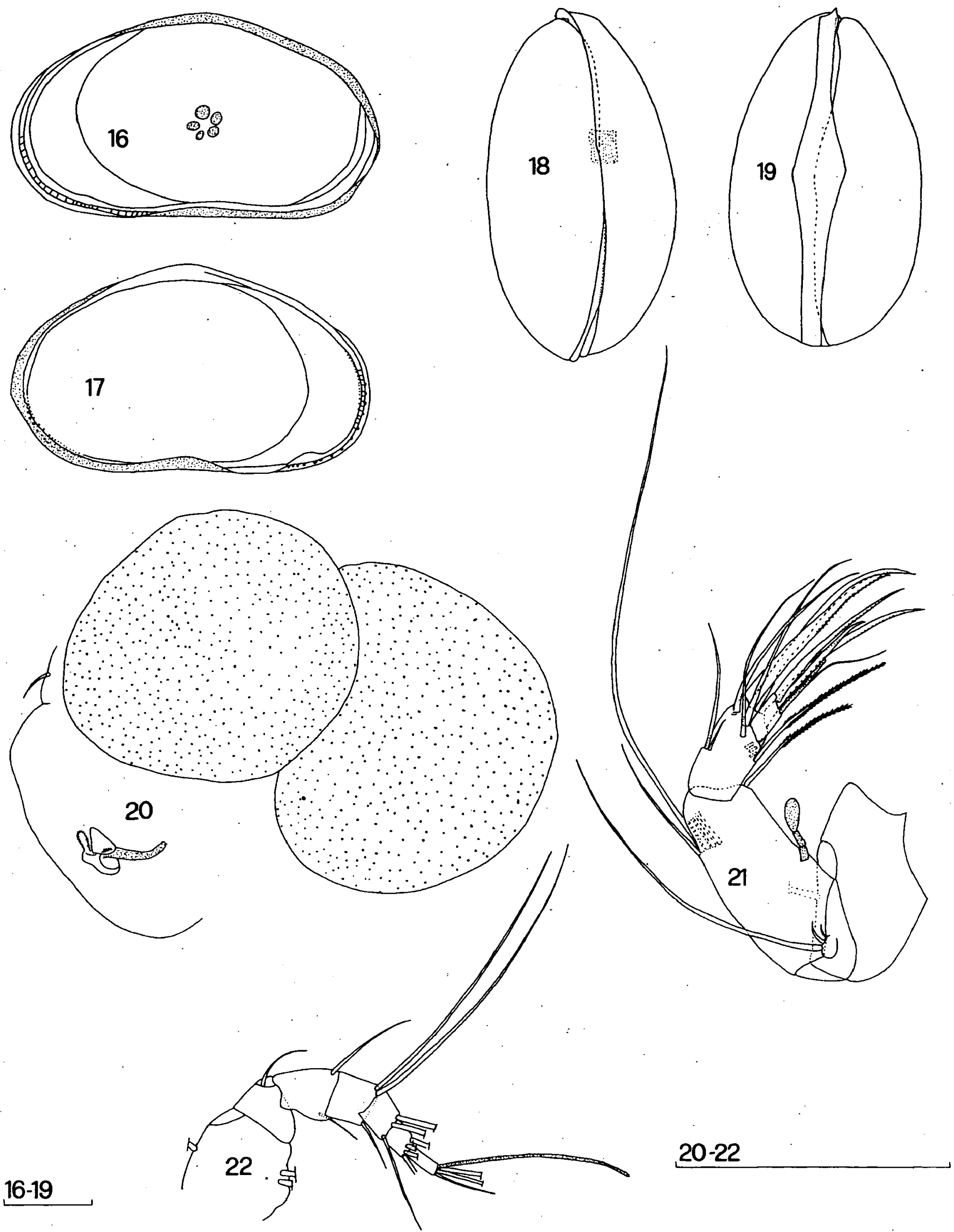

Figs. 16-22. Martenscypridopsis materia $\mathrm{n}$. gen., n. sp ; 16-17 paratype female (female $0.419 \mathrm{~mm}$ ) ; 18-22 allotype (female 0.388 mm). 16-RV, internal view ; 17-LV, internal view ; 18-carapace, dorsal view ; 19-carapace, ventral view ; 20-genital segment with eggs ; 21 -antenna ; 22antennula. Scale $=0.1 \mathrm{~mm}$

Figs. 16-22. Martenscypridopsis materia n.gen., n.sp. 16-17 paratype (femelle 0,419 mm); 18-22 allotype (femelle $0,388 \mathrm{~mm})$. 16-valve droite, vue interne ; 17-valve gauche, vue interne ; 18-carapace, vue dorsale ; 19-carapace, vue ventrale ; 20-segment génital avec les œufs ; 21 -anterine ; 22-antennule. Echelle $=0,1 \mathrm{~mm}$. 
le palps asymmetrical (figs 6 and 7). Right one with narrow and elongated finger, while left one (fig. 7) with stout and wide finger. Respiratory plate with 5 rays. Walking leg (fig. 9) 5-segmented, with all setae covered with fine setulae. Setae on first and second endopodal segments very long. Terminal claw slightly serrated and 1.2 times longer than 3 terminal segments combined. Cleaning leg (fig. 13) 4-segmented. Protopodite with 3 setae ; first and second endopodal segments with 1 short hirsute setae each. Terminal segment very small, Pincer-shaped, with 1 seta, a tonguelike structure and small spine. Hemipenis (fig. 8) with obtuse proximal and elongated distal shield. Distal shield with markedly developed hollow. Outer margin of distal shield more widely rounded than inner one. Zenker's organ with 7 whorls of spines.

Description of female (Allotype) : $\mathrm{L}=0.388 \mathrm{~mm}$. Maximum $\mathrm{H}=58 \%$ of $\mathrm{L}$, situated around middle. Maximum W $=54 \%$ of $\mathrm{L}$, situated around middle. RV with more inclined dorsal margin towards caudal margin than in male, so frontal margin clearly wider than caudal one and without tubercles on postero-ventral side. Inner list also more markedly developed than in male. LV with very minute teeth caudally, near inner margin, and with same teeth frontally near line of concrescence. In dorsal view (fig. 18) LV more clearly overlaps RV caudally. Other characteristics of carapace same as in male. Antenna (fig. 21) with all z-setae well developed ; swimming setae longer than in male. Claw G2 more strongly serrated than other claws. G1 1.6, G2 1.48, G3 1.5, GM 1.4, and Gm 0.9 times as long as first endopodal segment. All t-setae developed. First thoracic leg without special characteristics. Genital segment (fig. 20) rounded, with weakly developed copulatory hooks. Eggs very big, comparing with animal. Furca completely missing. A1, mandibule, walking, and cleaning legs same as in male.

\section{Discussion}

Martenscypridopsis $\mathrm{n}$. gen. belongs to the group of genera where the RV overlaps the LV both anteriorly and ventrally. As such, it is easy to distinguish it from the following Cypridopsinae genera (where LV overlaps the RV anteriorly and ventrally) : Cypridopsis Brady, 1864 ; Zonocypris G.W. Muller, 1898 ; Tungucypridopsis Victor, 1983 ; Cavernocypris Hartmann, 1964 ; Neocypridopsis Klie, 1940 and Pseudocypridopsis Karanovic, 1999. In this group of genera the genus Pseudocypridopsis has one very important common feature with Martenscypridopsis n. gen. Namely, those are the only two genera within the subfamily where the furca is completely missing in males as well as in females. The same anterior and ventral overlapping of valves, as in Martenscypridopsis n. gen., have the following genera: Plesiocypridopsis Rome, 1965 ; Sarscypridopsis McKenzie, 1977 ; Potamocypris Brady, 1870 ; Tanganyicacypridopsis Martens 1985 ; Klieopsis Martens, Meisch \& Marmonier, 1989 ; Bryopsis Roen, 1965 and Kapcypridopsis McKenzie, 1971. In the genus Austrocypridopsis McKenzie, 1982 ventral overlapping of the valves is not completely clear. According to McKenzie (1982) : "right valve slightly larger than left valve", but unfortunately McKenzie (1982) has never mentioned the ventral closure of the carapace. However, from all those genera, where RV overlaps the left both anteriorly and ventrally, including also Austrocypridopsis, the new genus can be easily distinguished by the absence of furca in both sexes. In the endemic genus Tanganyicacypridopsis, like in Martenscypridopsis, LV caudally overlaps RV, and also on the LV clear flange is developed caudally. The new genus comes very close to the genera Sarscypridopsis and Plesiocypridopsis. Similar appearance of the hemipenis is the main common feature of Martenscypridopsis and Sarscypridopsis. Also some representatives, i. e. Sarscypridopsis ochacea (Sars, 1924), have well developed flange caudally on the LV, and some, like Sarscypridopsis trigonella (Sars, 1924), have rows of small marginal tubercles (see Martens et al. 1996). But species of the genus Sarscypridopsis are bigger than those of Martenscypridopsis, hemipenis does not posses such a hollow as in Martenscypridopsis, and the females posses a distinct furca. Martens (1984) included species Cypridopsis pigmea Sars, 1924 into the genus Sarscypridopsis probably because of similarity of the valve form and hemipenis. Klie (1944), in the description of the females of this species, collected in Zaire, claimed : "Eine Furka konnte ich in keinem meiner Praparate auffinden, selbst nicht in den ausschliesslich zum Zwecke ihres Nachweises angefertigen." After finding of Martenscypridopsis materia n. sp., it is now clear that the lack of furca in both sexes is one of the main generic features, so this species must be included into the genus Martenscypridopsis n. gen. We have also to mention here that McKenzie (1971) cited the species as "Cypridopsis" pyg$m e a$, as a personal sign that it obviously does not belong to the genus Cypridopsis. Martenscypridopsis materia, by the appearance of carapace, is very similar whith the species Cypridopsis humilior described from Madagascar (Gauthier 1934), and later on found also in Kenya (Klie 1939). Martens (1984) transfered this species into the genus Plesiocypridopsis, on the base of the furcal appearance and carapace closure. This species is also very small $(0.42 \mathrm{~mm})$, and except the 
appearance of the valves, female's antenna is also very similar whith that of Martenscypridopsis materia $\mathrm{n}$. $\mathrm{sp}$. But, besides the presence of furca in females, $P$. $h u$ milior has more equally rounded dorsal margin, narrower caudal margin on the $\mathrm{LV}$ and also this margin is not inclined towards the ventral one, as it is in $M$. materia. Martenscypridopsis materia is similar with Plesiocypridopsis dubia, described from Sumatra (Sars 1903) and found also in India (Victor \& Fernando 1979). This species was also described in the genus Cypridopsis, and later transfered into Plesiocypridopsis by Martens (1984). The new species is also similar with Cypridopsis cf. dubia found in Chad (Gauthier 1939). Although Gauthier (1939) did not describe it as a new species, he was not so sure about the correct determination so he wrote :"Je propose donc d'identifier momentanément l'espèce que je viens de décrire avec la $C$. dubia de Sars. Mais ce n'est que lorsque celle-ci aura été retrouvée à Sumatra et décrite minutieusement que l'on pourra dire si cette détermination doit être maintenue". Probably, they are not the same species because neither Sars (1903) nor Victor \& Fernando (1979) mentioned small tubercles on the frontal end of $\mathrm{LV}$, which are clearly developed in Cypridopsis cf. $d u$ bia. There are also some other small differences in the appearance of the carapace, but its belonging to the genus Plesiocypridopsis, on the basis of furcal form and carapace closure, is certain. For neither of above mentioned species, from the genus Plesiocypridopsis, males are known. Plesiocypridopsis dubia and Plesiocypridopsis cf. dubia differ from Martenscypridopsis materia, except by the presence of furca, also by more evently rounded dorsal margin and not inclined postero-ventral margin on the LV. Plesiocypridopsis dubia does not posses tubercles at all, while $P$. cf. dubia possesses them only on the frontal end of the LV. Also, the subfossil species Sarscypridopsis cf. pygmea found in north-west Sudan (Schoning 1994) is probably the same species which Gauthier (1934) determined as $C y$ pridopsis cf. dubia, because it has almost identical valve shape and also it has tubercles only on the anterior end of LV. Two species from the genus Martenscypridopsis, M. materia n. sp. and M. pygmea (Sars, 1924), are very close but they can be easily distinguished by the following characteristics :

1. M. pygmea does not possess tubercles neither on anterior nor on posterior end of LV or RV ;

2. the anterior end of carapace is narrower than posterior one in $M$. pygmea, while it is wider (or both ends are equally wide) in $M$. materia ;
3. maximum W in $M$. pygmea is less then $45 \%$ of $\mathrm{L}$, in $M$. materia it is more than $50 \%$ of $\mathrm{L}$;

4. the recession on the distal shield of hemipenis is greater in $M$. pygmea, and its outer edge is clearly narrower than in $M$. materia.

\section{References}

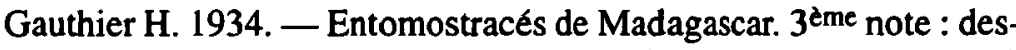
cription d'une nouvelle Cypridopsis (Ostracoda). Bull. Soc. zool. Fr., 59 : 73-85.

Gauthier H. 1939. - Contribution à l'étude de la faune dulcaquicole de la région du Tchad et particulièrement des Branchiopodes et des Ostracodes. Bull. Inst. fr. d'Afr. Noire, 1 : 110-244.

Karanovic I. 1999. - On Pseudocypridopsis n. gen, with a redescription of Pseudocypridopsis clathrata (Klie, 1936) and a first description of the male (Ostracoda, Cypridopsinae). Bull. Zool. Mus. Univ. Amsterdam, 17 : 1-8.

Klie W. 1939. - Otracoden aus dem Kenia-Gebiet, vornehmlich von dessen Hochgebirgen. Int. Rev. Hydrobiol. Hydrogr., 39 99-161.

Klie W. 1944. - Exploration du Parc National Albert, Mission H Damas (1935-1936). Inst. Parc Nation. Congo Belge, 12 : 1-62.

Martens K. 1984. - Annotated checklist of non-marine ostracods (Crustacea, Ostracoda) from African inland waters. Mus. Roy. Afr. Centr. Tervuren-Belg., Doc. Zool., 20 : 1-51.

Martens K. 1985. - Tanganyicacypridopsis gen. n. (Crustacea, Ostracoda) from Lake Tanganyika. Zool. Scr., $14: 221-230$.

Martens K. 1991. - On Klieopsis n. gen., with a redescription of Cypridopsis horai Klie 1927 (Crustacea, Ostracoda). Bull. Inst. Roy. Sci. Nat. Belgique, Biologie, 6 : 55-64.

Martens K. 1998. - General morphology of non-marine ostracods. In : Martens, K. (Ed.), Sex and parthenogenesis : evolutionary ecology of reproductive modes in non-marine ostracods : 57-75, Leiden, The Backhuys Publishers Netherlands.

Martens K, Davies B.R., Baxter A.J. \& Meadows M.E. 1996. - A contribution to the taxonomy and ecology of the Ostracoda (Crustacea) from Verlorenvlei (Western Cape, South Africa). S. Afr. J. Zool., $31:$ 23-36.

McKenzie K. 1971. — Species list of South African Freshwater Ostracoda with an appendix listing museum collections and some further determinations. Ann. S. Afr. Mus., $57: 157-213$.

McKenzie K. 1982. - Description of a new Cypridopsinae genus (Crustacea, Ostracoda) from Campbell island, with a key to the Cypridopsinae. Proc. Biol. Soc. Washington, 95 : 766-771.

Sars G.O. 1903. - Fresh-water entomostraca from China and Sumatra. Arch. Matem. Naturv., $25: 1-44$.

Sars G.O. 1924. - The freshwater Entomostraca of the Cape province (Union of South Africa). Ostracoda. Ann. S. Afr. Mus., 20 : 105-193.

Schoning C. 1994. - Zur Kenntnis der subfossilen Ostracoden des nordwestlichen Sudans. Mitt. hamb. zool. Mus. Inst., 91 : 91-108.

Victor R. \& Fernando C.H. 1979. - The freshwater ostracods (Crustacea, Ostracoda) of India. Rec. Zool. Surv. India, 74 : 147-242

Vigna Taglianti A., Cottarelli V. \& Argano R. 1969. - Messa a punto di metodiche per la raccolta della fauna interstuziale e freatica. Arch. Bot. e Biogeogr. it., 14 : 375-380. 